\title{
Environmental aspect of maintenance of buildings with ETICS
}

\author{
Katarína Minarovičová ${ }^{1, *}$ \\ ${ }^{1}$ Department of Building Constructions, SUTechnology Bratislava, Faculty of Civil Engineering, \\ Radlinského 11, 81005 Bratislava, Slovakia
}

\begin{abstract}
Treatment of existing External Thermal Insulation Composite System (ETICS) is based mainly on chemical methods while environmental impacts are not clear. Currently used finishes of ETICS contain biocides as a prevention measure against biocorrosion. Uncontrolled leaching of biocides is not longer acceptable. Research on new technologies without uncontrolled release of biocides is developing, however, new system solutions are not known yet. Principles of sustainability must be regarded when applying the concept of ETICS maintenance.
\end{abstract}

\section{Introduction}

External Thermal Insulation Composite System (ETICS) is protected from microbial attack by use of biocides mostly in base or finish coat/paint. Use of biocides and their presence in the natural environment can affect fauna and flora even at low concentrations $[1,2,3]$. Several studies were conducted to find out the effect of biocides leaching to groundwater and sewage system [2]. Researchers develop models for façade leaching of biocides to find a suitable prediction method e.g. $[2,4,5]$ and thus regulate the amount of biocides leaching from facades and other constructions to stormwater, wastewater and surface waters.

Deep study on water driven leaching of biocides [6] revealed that some compounds were present in storm water in levels sometimes exceeding receiving water quality standards, biocides were present also in dry weather wastewater as well as in rain weather combined sewer. Other monitoring studies showed that biocides are leaching in substantial amounts to the environment and can be detected and assessed. Leaching behaviour of biocides and toxicity of leachates from renders have been assessed by researchers [3-8]. Latest research studies confirmed that substances released from facades and buildings can be transported, accumulated, degraded, and also uptaken by living organisms, including humans [7].

\footnotetext{
*Corresponding author: katarina.minarovicova@stuba.sk
} 


\section{ETICS maintenance}

It is very important to take into account reliability and maintainability of the construction in the whole life cycle of a building. Operation and maintenance is an important part the life cycle cost of a building. One of the most common and most visible defects of facades with ETICS is biocorrosion- colonization of facades by microorganisms (especially bacteria, cyanophytes, algae and fungi). Biocorrosion needs to be treated immediately. Thus immediate operative intervention and efficient technologies for destruction of microorganisms are required while long-term secondary prevention against colonization of ETICS is used. There is technology provided (figure 2):

- Conservative (technology with minimal intervention to the original layers of ETICS)

- Radical (technology with mechanical modifications of original layers of ETICS).

The removal of bio corrosion coating from ETICS structure as well as preventive treatment with chemical and preservative substances (biocides) is currently the only effective and most used technology.

Conservative technology consists of decontamination and repair with subsequent maintenance that is part of secondary prevention. It is a direct chemical intervention eliminating the entire living micro flora by combining mechanical and chemical action. This type of technology is considered as a barrier protection of the ETICS against the colonization of microorganisms. Like other conservative technologies, the barrier protection of micro-organisms requires the periodicity throughout the life of the ETICS.

Radical technology also requires regular monitoring and subsequent maintenance during the life of the ETICS. Radical technology is considered as a technology with volume protection
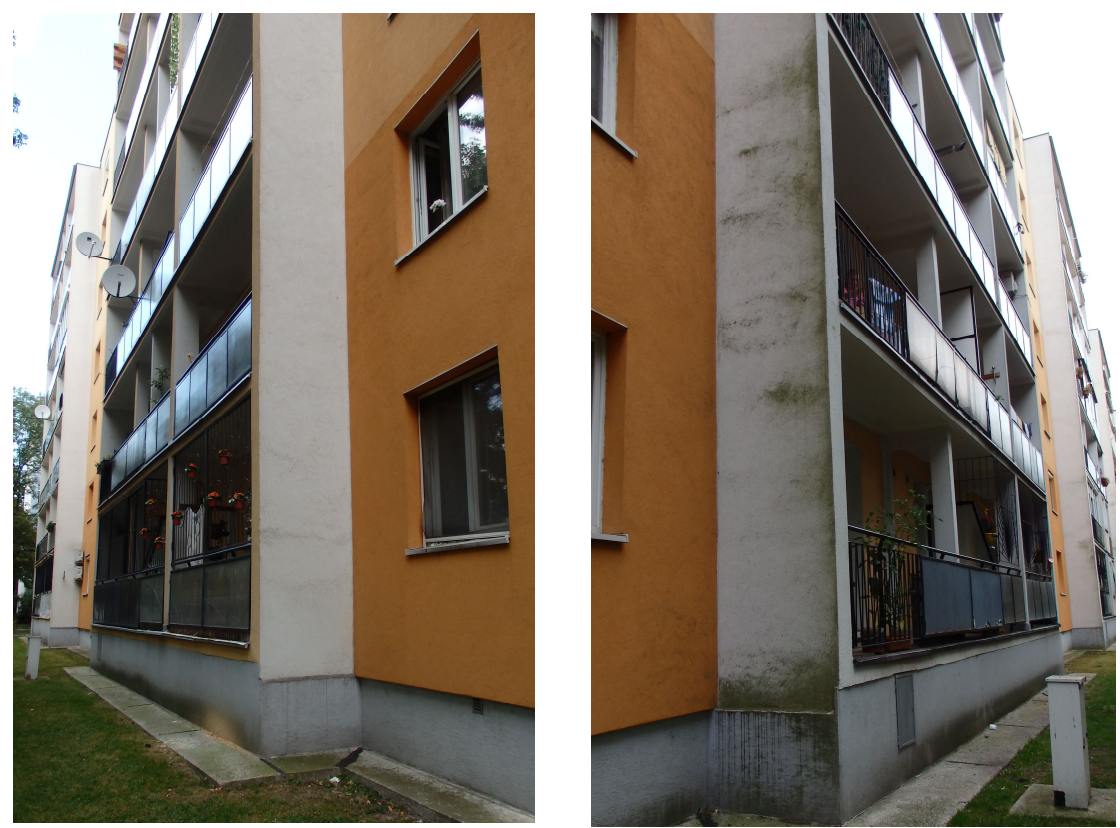

Fig. 1. Façade with biocorrosion on ETICS- southern and northern loggia element (Bratislava) 


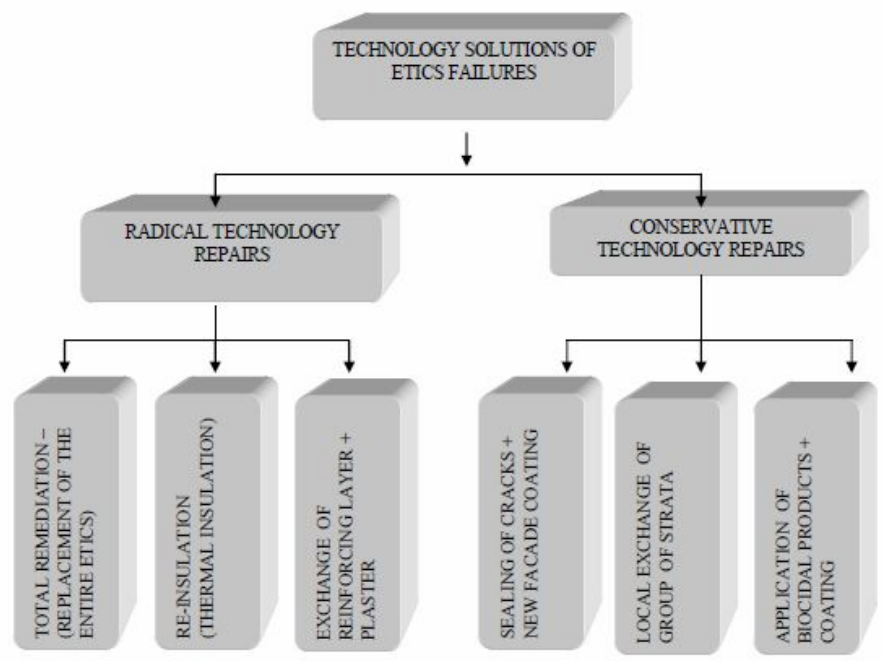

Fig. 2. Repair and remediation measures of ETICS $[11,12]$

In practice most of the technological solutions for ETICS remediation begin to plan at a time when failures are being already identified on the construction. The cost of a remediation and protection of constructions executed before the development of any failures is only a fraction of the total costs invested in the reconstruction or renovation of the facade [13].

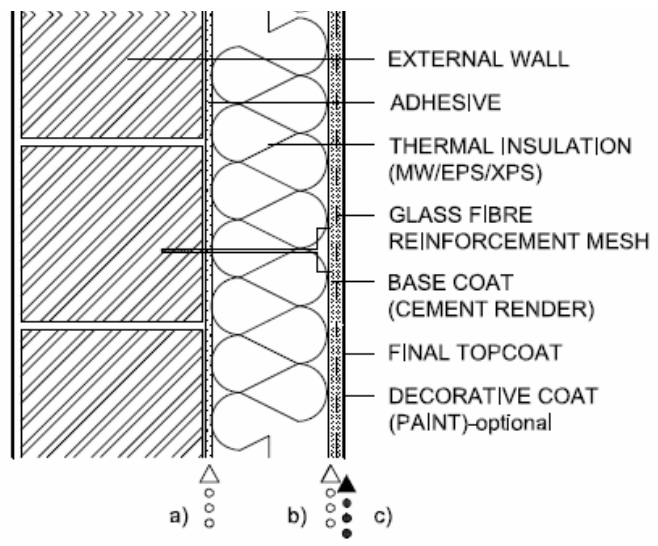

Fig. 3. External thermal insulation composite system (ETICS) with location of possible use of biocides: a) after replacement of the ETICS construction with bio corrosion (radical technology), b) after replacement of reinforcement layer (radical technology), c) after cleaning and biocidal treatment (conservative technology) or as an original finish coat with biocide compounds (preventive measure). (author) 


\section{Regulatory contexts}

"Hygiene, health, and the environment" is a category of the basic requirements for construction works in European construction products regulation [14, 15]. The Technical report CEN/TR 17005 of 2016 [16] recommends additional impact categories as human toxicity, eco toxicity, particulate matter, land use, biodiversity, water scarcity and ionizing radiation. Other technical report - CEN/TR 17105 [17] deals with assessment of release of dangerous substances and guide on the use of ecotoxicity tests applied to construction products.

The Technical Committee, CEN TC 351 "construction products: assessment of release of dangerous substances", have developed two laboratory test procedures to determine the amount of substances released into water. To receive reliable and comparable results, it is strongly recommended [7] to apply only standardized ecotoxicity methods, giving preference to those referred to in the CEN/TR 17105 guidance [17]. Ecotoxicity is considered in Life Cycle Analysis (LCA) assessments as an additional-impact LCA category.

Results of ecotoxicological analyses are expressed in the form of ecotoxicological indexes - LOEC (lowest observed effect concentration), EC50 (effective concentration causing 50\% effect in a comparison to control), and LC50 (lethal concentration causing $50 \%$ effect in a comparison to control) [7].

The assessment of ecotoxicity of materials is ruled by Regulation (EC) No 1272/2008 on classification, labelling and packaging of substances and mixtures. The production and use of chemical substances, and their potential impacts on both human health and the environment in the European Union (EU) is subjected to the REACH - Regulation (EC) No 1907/2006 of the European Parliament and of the Council of 18 December 2006 concerning the Registration, Evaluation, Authorisation and Restriction of Chemicals (REACH). Biocidal products used in facade coatings are submitted to the environmental risk assessment under the Biocidal Products Regulation (EU) No 528/2012 concerning the making available on the market and use of biocidal products.

\section{Conclusions}

Research performed in laboratory conditions should be combined with experiment in situ. One of the results of various studies is the significant effect of wind driven rain on facade. The leaching is influenced also by the organic binder content in coat (render) giving less leaching and can be controlled by the organic fraction in the render. Changes in the $\mathrm{pH}$ induce different desorption behaviour, construction material and compound properties may also influence the leaching process.

Uncontrolled leaching of the used biocides is unacceptable. Leaching should be predictable, regulated and the amount of leached compounds comparable. New knowledge on compounds behaviour in leachates should be incorporated in legislation and in new technologies for prevention and remediation of facades with biocorrosion on ETICS.

One of the possibilities is use of biological biocides (enzymes, parasites, plants etc.). Finally, biocides used for the protection of facades should be non-persistent, nonbioaccumulative and non-toxic to organisms. However, the residues of some biocides can be more toxic than parental compounds and it is not exactly known yet how some of them behave in mixtures with other chemicals [7].

Future tasks for research and practice is to find reliable measure to decrease and control leaching of biocides (use mainly encapsulated biocides, biocides in halloysite clay nanotubes etc.) and a measure to decrease use of biocides (using alternative- environment 
friendly biocides). In the case we can't avoid use of biocides based on heavy metals it is inevitable to control the release of biocides and its transport to surface and groundwater.

The paper partly originated within the framework of the Scientific Grant Agency of VEGA 1/0685/16 project.

\section{References}

1. I. Wittmer, M. Burkhardt, EAWAG News, 67 (2009)

2. S. Coutu, C. Rota, L. Rossi, D.A.Barry, Water Research, 46, 11, (2012)

3. N. Bandow, S. Gartiser, O. Ivonen, U. Schoknecht, Environmental Sciences Europe, 30, 14, (2018)

4. I.K.Wittmer, R. Scheidegger, C. Stamm, W. Gujer, H.P. Badera, Water Research, 45, $11,(2011)$

5. B. Hensen, J. Lange, N. Jackisch, F. Zieger, O., K. Kümmerer, Water Research 144 (2018)

6. K. Bester, J. Vollertsen, U. E. Bollmann, (DEPA, 2014)

7. K. Kobetičová, R. Černý, Journal of Cleaner Production 165, (2017)

8. L.M. Vermeirssen, S. Campiche, C. Dietschweiler, I. Werner, M. Burkhardt, Environmental toxicology and chemistry, 37, 8 (2018)

9. U. E. Bollmann et al., Scientific reports 7, (2017)

10. I. K. Wittmer, Water research 45, 11 (2011)

11. Petro, M. (Tribun EU 2013)

12. N. Antošová, M. Ďubek, M. Petro (Taylor \& Francis Group, 2017)

13. Antošová, N., Realizácia a ekonomika stavieb. (Trenčianske Teplice, 2009)

14. Regulation (EU) No 305/2011 laying down harmonised conditions for the marketing of construction products and repealing Council Directive 89/106/EEC (2011)

15. Report from the commission to the EP and the council on the implementation of Regulation (EU) No 305/2011 (2016)

16. TNI TR 17005 Sustainability of construction works. Additional environmental impact categories and indicators. Background information and possibilities. Evaluation of the possibility of adding environmental impact categories and related indicators and calculation methods for the assessment of the environmental performance of buildings (2017)

17. TNI CEN/TR 17105 Construction products. Assessment of release of dangerous substances. Guidance on the use of ecotoxicity tests applied to construction products (2017)

18. N. Antošová, M. Ďubek, M. Petro, ESaT 2016, (Technical University of Košice, Faculty of Civil Engineering, 2016) 